\title{
THE STUDY OF CHELATING RESIN DOWEX XUS 43605 FOR COPPER RECOVERY FROM NICKEL LATERITE LEACH SOLUTION
}

\author{
Isadora Dias Perez' \\ Amilton Barbosa Botelho Junior ' \\ Denise Crocce Romano Espinosa '
}

\begin{abstract}
The extraction of metals from nickel laterite ores has been increasing, due to the demand for copper, nickel and cobalt. HPAL is a hydrometallurgical process which uses sulfuric acid as leaching agent. After the leaching step, ion exchange techniques are used to recover metals selectively, as well as chelating resins. The goal of this work was to study the use of Dowex XUS 43605 for copper recovery from nickel laterite leach solution. Mono- and multielementary solutions were studied and results compared the effect of other metal ions on copper adsorption. As previous study showed, iron is the main contaminant in solution. However, the use of Dowex XUS 43605 is not explored in the literature. The effect of time, $\mathrm{pH}$, copper concentration, mass of resin and temperature were evaluated. Results showed that copper adsorption was $100 \%$ using monoelementary solutions and $72 \%$ in multielementary solution at $\mathrm{pH}$ I.5 after $120 \mathrm{~min}$, where the resin was more selective for copper. The use of high quantity of resin decreased the adsorption capacity. Temperature had no effect on copper adsorption. These results are important to develop industrial process of nickel laterite extraction.
\end{abstract}

Keywords: Hydroxypropyl-picolylamine; HPPA; ion exchange; hydrometallurgy.

\section{INTRODUCTION}

Nickel laterite represents $70 \%$ of nickel resources and $40 \%$ of nickel production, which it is possible to recover copper and cobalt $[1,2]$. The main problem of metals extraction from those resources is the high content of iron, which may make the process unfeasible $[3,4]$. The process to extract nickel, cobalt and copper from nickel laterite resources is The High Pressure Leaching Process (HPAL). Sulfuric acid is used as leaching agent at $240^{\circ} \mathrm{C}$ and 40 bar. The liquor obtained needs to be purified [4].

Among the techniques that can be used to purified the liquor, the ion exchange process has few advantages, such as the high concentration of iron. The solvent extraction can be used, as Aliprandini [5] showed. A solvent extraction process was developed and $100 \%$ of nickel from the liquor was purified. However, cobalt and high concentration of iron were extracted using Cyanex 272 20\%. Copper extraction was possible using Acorga M5640 5\%.

Another ion exchange technique is the use of chelating resins, which are selectivity to specific metals present in solution [4,6,7]. Botelho et al. [3] showed that it is possible to recover nickel and cobalt using chelating ion exchange resins. The continuous experiments were performed in columns, where the first column was used to remove copper from solution. Nickel and cobalt recovery efficiency was $79.3 \%$ and $77.9 \%$, respectively [8]. Nonetheless, process efficiency has been hampered by the first column, where the chelating resin Lewatit TP 207 adsorbed I 7\% of nickel. For this reason, the study of chelating resin to recover copper with high efficiency and low adsorption of other metals must be considered.

The goal of this work was to study the use of chelating resin Dowex XUS 43605 for copper recovery from nickel laterite leach solution and the effect of other metals. Experiments with monoelementary solutions were performed to evaluate copper adsorption by the chelating resin. The effect of time reaction, the $\mathrm{pH}$ and concentration of copper were evaluated. Multielementary solution was prepared to simulate the real nickel laterite leach solution. Then, experiments were performed to study the effect of other metal ions on copper recovery. The effect of $\mathrm{pH}$, mass of resin and temperature were studied. Samples were analyzed on X-ray fluorescence equipment (EDXRX).

\section{MATERIALS AND METHODS}

\section{I Materials}

Synthetic solution was prepared to simulate the real nickel laterite leach solution. Sulfate salts of each metal was dissolved in deionized water. Metals concentration is presented in Table I. The $\mathrm{pH}$ was adjusted to 0.5 using sulfuric acid P.A.

'Departamento de Engenharia Química, Escola Politécnica, Universidade de São Paulo - USP, São Paulo, SP, Brasil. E-mail: amilton.junior@usp.br 
Copper monoelementary solutions were prepared to study the ion adsorption by the resin and multielementary solution with all metals presented in leach solution to evaluate the copper adsorption efficiency.

The chelating resin studied was Dowex XUS43605 with hydroxypropyl-picolylamine functional group (HPPA) and particle size 0.32 . The theoretical selectivity order is $\mathrm{Cu}(\mathrm{II})>>\mathrm{Ni}(\mathrm{II})>\mathrm{Fe}(\mathrm{III})>\mathrm{Zn}(\mathrm{II})>\mathrm{Co}(\mathrm{II})>\mathrm{Cd}(\mathrm{II})>\mathrm{Fe}(\mathrm{II})[$ [-I I ] Figure I shows the HPPA functional group [12]. The resin was washed with hydrochloric acid $6 \mathrm{~mol} / \mathrm{L}$ and sodium hydroxide $2 \mathrm{~mol} / \mathrm{L}$ in three steps, following the order $\mathrm{HCl}$-deionized water- $\mathrm{NaOH}$-water deionized. Then, the resin was died in stove at $60^{\circ} \mathrm{C}$ during 24 hours.

\subsection{Methods}

lon exchange experiments were performed in erlenmeyer flasks with $\mathrm{Ig}$ of resin and $50 \mathrm{~mL}$ of solution in shaker at 200rpm. Experiments with copper monoelementary solution were performed to study the ions adsorption by the resin. The effect of time was studied between 30-1440min and the

Table I. Concentration of elements present in synthetic solution of nickel laterite leach solution, in $\mathrm{mg} / \mathrm{L}$

\begin{tabular}{llllllllll}
\hline Element & $\mathrm{Al}$ & $\mathrm{Co}$ & $\mathrm{Cr}$ & $\mathrm{Cu}$ & $\mathrm{Fe}$ & $\mathbf{M g}$ & $\mathbf{M n}$ & $\mathbf{N i}$ & $\mathbf{Z n}$ \\
\hline
\end{tabular}

$\begin{array}{llllllllll}\text { Conc. } \mathrm{mg} / \mathrm{L} & 4,101 & 78 & 195 & 146 & 18,713 & 7,774 & 397 & 2,434 & 36\end{array}$

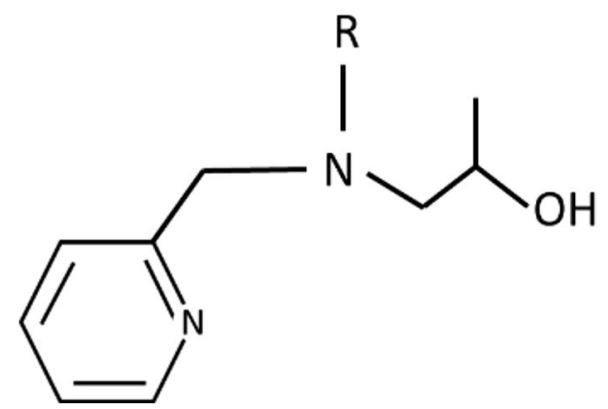

Figure I. The hydroxypropyl-picolylamine functional group of Dowex XUS 43605 chelating resin [12].

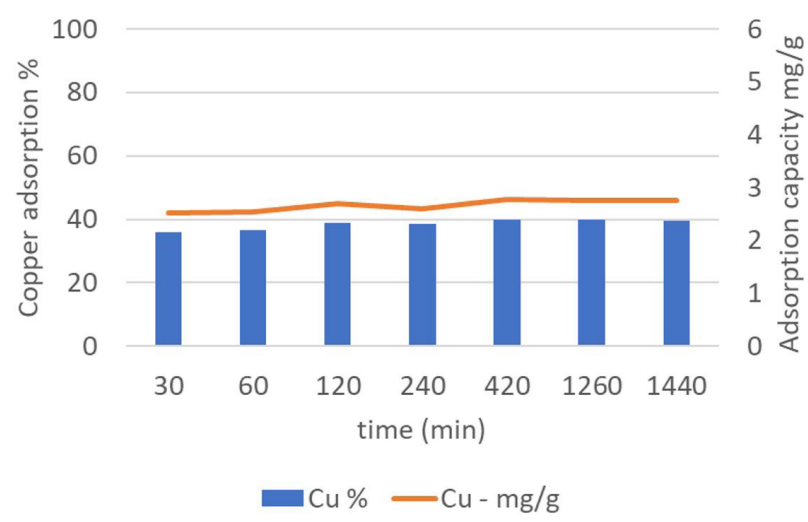

Figure 2. Percentage of copper ions adsorbed and adsorption capacity $(\mathrm{mg} / \mathrm{g})$ during the time $(30-1440 \mathrm{~min})$ using $\mathrm{Ig}$ of resin, $50 \mathrm{~mL}$ of solution and $\mathrm{pH} 0.5$ at $25^{\circ} \mathrm{C}$. effect of $\mathrm{pH}$ was studied between $0.5-2.0$. The concentration of copper was studied between $70-400 \mathrm{mg} / \mathrm{L}$.

Experiments with multielementary solution were performed to study the effect of other ions from nickel laterite leach solution on copper adsorption. The effect of $\mathrm{pH}$ between 0.5-2.0 and mass of resin between 0.055-7g were evaluated. Thermodynamics experiments were performed between $25-60^{\circ} \mathrm{C}$. Samples were analyzed in FRX. Equation I was used to quantify the mass of ions adsorbed per mass of resin $(\mathrm{mg} / \mathrm{g})$. Equation 2 was used to quantify of ion was adsorbed, in percentage $[3,13,14]$.

$$
\begin{aligned}
& q_{t}=\left(C_{0}-C_{t}\right) \times \frac{v}{m} \\
& \% S=\frac{\left(C_{0}-C_{t}\right)}{C_{0}} \times 100 \%
\end{aligned}
$$

qt: capacity of ion adsorbed in time $t$ in mass of ion per mass of resin $(\mathrm{mg} / \mathrm{g})$;

$\mathrm{C}_{0}$ and $\mathrm{C}_{\mathrm{t}}$ : concentration of ions in time $=0$ and time $=\mathrm{t}(\mathrm{mg} / \mathrm{L})$; $\mathrm{v}$ : volume of solution $(\mathrm{L})$; $\mathrm{m}$ : the mass of resin $(\mathrm{g})$

The $\mathrm{pH}$ was studied to verify the effect of $\mathrm{H}^{+}$ions on metals adsorption, where the $\mathrm{H}^{+}$ions concentration decreases when the $\mathrm{pH}$ increases. As a result, the metals adsorption increases. The kinetics of adsorption was studied to verify when the reaction react the equilibrium. The effect of copper concentration was studied in order to determine the adsorption limit. The temperature was studied to verify if the reaction is endothermic or exothermics.

\section{RESULTS AND DISCUSSION}

\section{I Copper Adsorption in Monoelementary Solution}

\section{I.I Effect of time on copper monoelementary solution}

The effect of time on copper adsorption was studied at $\mathrm{pH} 0.5, \mathrm{Ig}$ of resin and $50 \mathrm{~mL}$ of solution at $25^{\circ} \mathrm{C}$. The time reaction studied were $30 \mathrm{~min}, 60 \mathrm{~min}, 120 \mathrm{~min}$, $240 \mathrm{~min}, 420 \mathrm{~min}, 1260 \mathrm{~min}$ and $1440 \mathrm{~min}$. Results are shown in Figure 2. Copper adsorption increased from $30 \mathrm{~min}$ to $120 \mathrm{~min}$, where reached the equilibrium. In $120 \mathrm{~min}$, the adsorption capacity was $2.7 \mathrm{mg} / \mathrm{g}$, which represents $38.8 \%$ of copper adsorption.

The difference on copper adsorption at $120 \mathrm{~min}$ and $240 \mathrm{~min}, 420 \mathrm{~min}, 1260 \mathrm{~min}$ and $1440 \mathrm{~min}$ was less than $5 \%$. Botelho et al. [8] verified that copper adsorption reached the equilibrium in $120 \mathrm{~min}$. The chelating resin studied by the authors has an iminodiacetate functional group (TP 207). For this reason, the following experiments were performed in 120 min. 


\section{I.2 Effect of $\mathrm{pH}$ on ions adsorption}

The effect of $\mathrm{pH}$ was studied in $120 \mathrm{~min}$, using $\mathrm{Ig}$ of resin and $50 \mathrm{~mL}$ of solution at $25^{\circ} \mathrm{C}$. Figure 3 shows the percentage of copper recovery. Copper adsorption increased from $38.8 \%$ at $\mathrm{pH} 0.5$ to $\mathrm{I} 00 \%$ at $\mathrm{pH} \mathrm{I} .5$ and 2.0 . The increase on metal adsorption when $\mathrm{pH}$ increases occurs due to the decrease of $\mathrm{H}^{+}$concentration in solution. The $\mathrm{H}^{+}$ions competes with metal ions for the functional group of chelating resin [15], and in $\mathrm{pH} \mathrm{I.5}$ all copper ions were adsorbed.

However, these experiments were performed with monoelementary solutions, and other metal ion present in solution should decrease copper recovery due to the competition among them. Also, previous studies depicted that iron precipitates in $\mathrm{pH}$ above 2.00 which causes the co-precipitation of copper and cobalt $[5, \mathrm{I}]$. For this reason, experiments in $\mathrm{pH}$ above 2.00 were not performed.

\subsubsection{Effect of concentration on ions adsorption}

Figure 4 shows the effect of copper concentration on ions adsorption. The concentrations studied were $70 \mathrm{mg} / \mathrm{L}$, $147 \mathrm{mg} / \mathrm{L}, 270 \mathrm{mg} / \mathrm{L}$ and $400 \mathrm{mg} / \mathrm{L}$. All copper was adsorbed in solutions with $70 \mathrm{mg} / \mathrm{L}$ and $147 \mathrm{mg} / \mathrm{L}$. However, ions adsorption decreases when copper concentration increased, where $69.5 \%$ of copper was adsorbed in solution with $400 \mathrm{mg} / \mathrm{L}$. It may have occurred due to the limit of activated sites of the resin, saturating the ions adsorption on the resin surface.

\subsection{Metals Adsorption on Synthetic Solution of Nickel Laterite Leach Solution}

The effect of copper adsorption in multielementary solution were performed to study the effect of contaminants of process efficiency. As previous study showed, iron is the main contaminant in solution [16]. However, the use of Dowex XUS 43605 is not explored in the literature. For this reason, the effect of contaminants was studied.

\subsection{The effect of $\mathrm{pH}$ on metals adsorption}

The effect of $\mathrm{pH}$ was studied to evaluate the effect of concentration of $\mathrm{H}^{+}$on metals adsorption. The presence of other contaminants for copper recovery was evaluated. Figure 5 shows the percentage of copper, iron and nickel adsorption. Aluminum, manganese, cobalt, chromium, magnesium and zinc were not adsorbed by the resin. Copper adsorption was $6.1 \mathrm{mg} / \mathrm{g}$ at $\mathrm{pH} 2.0$, while in monoelementary experiments it was $7.6 \mathrm{mg} / \mathrm{g}$. Iron and nickel adsorption were respectively 6.3 and I. 3 times higher than copper adsorption at $\mathrm{pH} 2.0$, due to the selectivity order of the chelating resin and concentration of those metals in solution.

Copper adsorption decreased from 100\% in monoelementary experiments to $72 \%$ in multielementary experiments at pH I.5. Jiménez Correa et al. [17] verified that copper recovery was $80 \%$ in $\mathrm{pH}$ between 0.5 and 2.0 using chelating resin Dowex M4I95 (bis-picolylamine

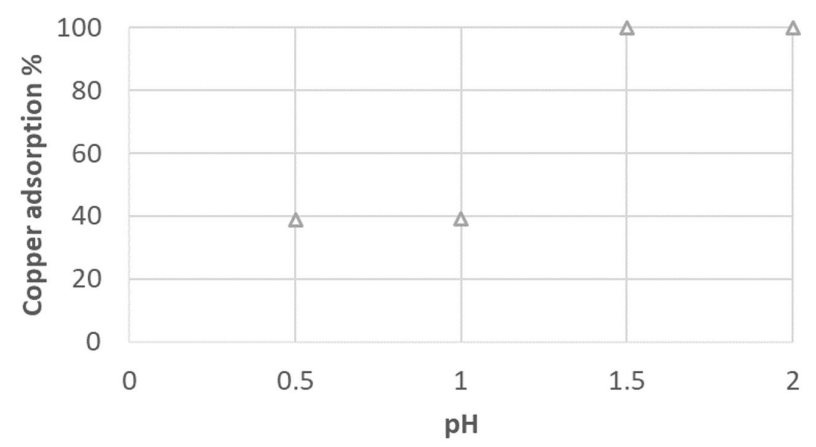

Figure 3. Percentage copper adsorbed for each $\mathrm{pH}$ studied in $120 \mathrm{~min}$, using $\mathrm{I} g$ of resin, $50 \mathrm{~mL}$ of solution at $25^{\circ} \mathrm{C} . \Delta=$ Percentage of copper ions adsorption.

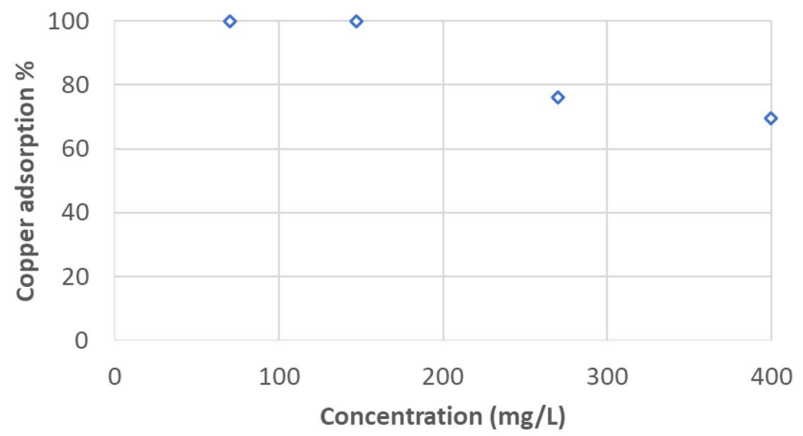

Figure 4. The effect of copper concentration in $120 \mathrm{~min}$, at $\mathrm{pH}$ I.5, using $\mathrm{Ig}$ of resin and $50 \mathrm{~mL}$ of solution at $25^{\circ} \mathrm{C}$. $\diamond=$ Percentage of copper ions adsorption.

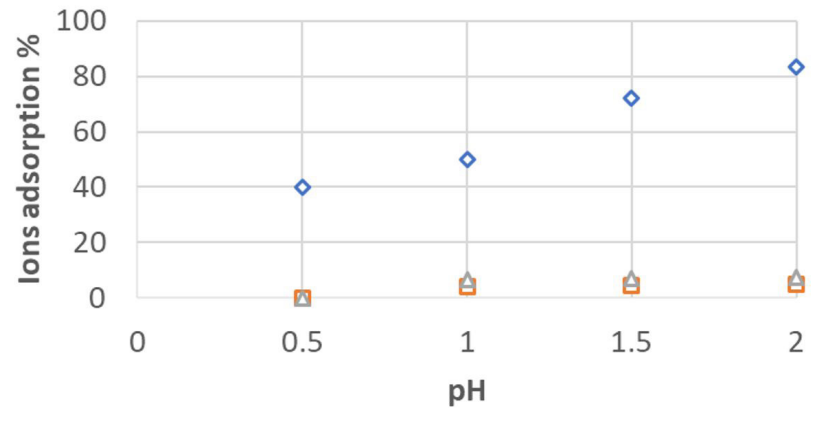

$\diamond \mathrm{Cu} \square \mathrm{Fe} \triangle \mathrm{Ni}$

Figure 5. Percentage ions adsorbed for each $\mathrm{pH}$ studied in $120 \mathrm{~min}$, using $\mathrm{Ig}$ of resin, $50 \mathrm{~mL}$ of solution at $25^{\circ} \mathrm{C}$.

functional group). It occurs due to the presence of other ions competing for the functional group of the chelating reins. Abbasi et al. [18] studied a chelating resin with iminodiacetate functional group and showed that iron is the main contaminant on nickel laterite leach solution, which decreases metals adsorption.

\subsubsection{The effect of mass of resin on metals adsorption}

The effect of mass of resin was studied for $0.055 \mathrm{~g}$, $0.25 \mathrm{~g}, 0.5 \mathrm{~g}, \mathrm{Ig}, 2.5 \mathrm{~g}, 4 \mathrm{~g}$ and $7 \mathrm{~g}$. In batch industrial process, the quantity of resin per volume of solution is important 


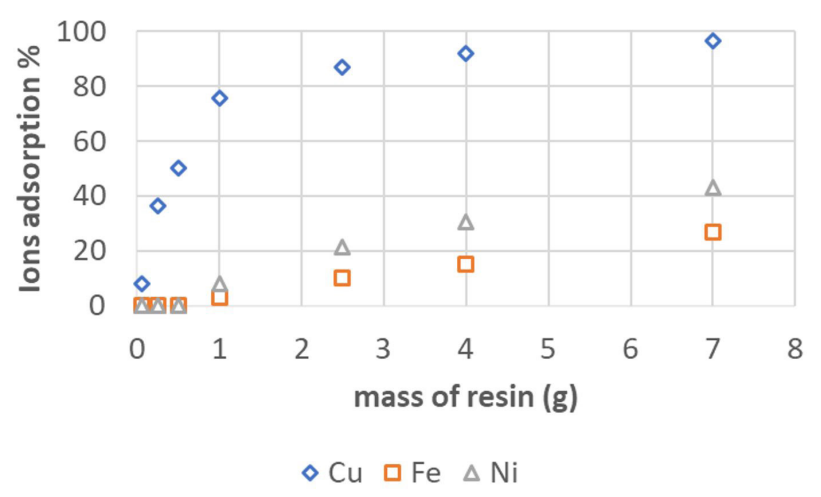

Figure 6. Percentage ions adsorbed for each mass of resin studied in $120 \mathrm{~min}, \mathrm{pH} 1.5,50 \mathrm{~mL}$ of solution at $25^{\circ} \mathrm{C}$.

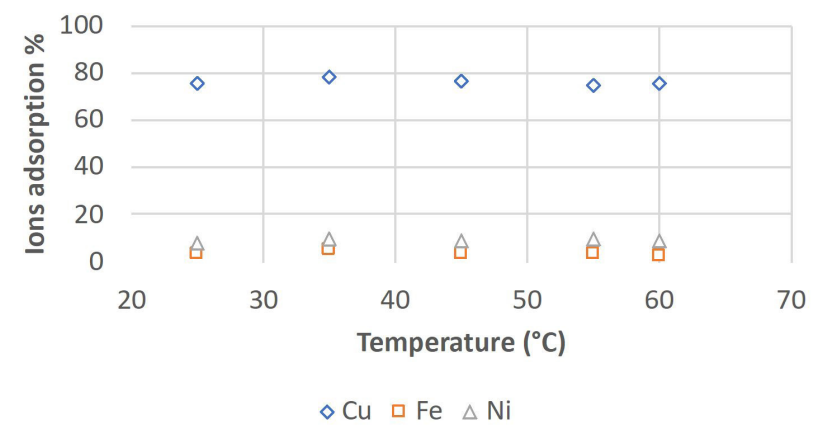

Figure 7. Percentage ions adsorbed varying the temperature in $120 \mathrm{~min}$, $\mathrm{I} g$ of resin, $\mathrm{pH} 1.5$ and $50 \mathrm{~mL}$ of solution.

for the economic and technical feasibility [19]. Experiments were performed at $\mathrm{pH} 1.5,50 \mathrm{~mL}$ of solution, during $120 \mathrm{~min}$ at $25^{\circ} \mathrm{C}$. Figure 6 presents the percentage of copper, iron and nickel adsorption. Aluminum, magnesium, manganese and zinc were not adsorbed. Metals adsorption increases when mass of resin increased. Chromium and cobalt were adsorbed using $2.5 \mathrm{~g}, 4 \mathrm{~g}$ and $7 \mathrm{~g}$ of resin. Iron and nickel were adsorbed in experiments with more than Ig of resin.

Copper adsorption increased from $7.9 \%(0.055 \mathrm{~g})$ to $96.6 \%(7 \mathrm{~g})$. However, the increase of mass of resin decreased the adsorption capacity from $10.9 \mathrm{mg} / \mathrm{g}$ to $1.1 \mathrm{mg} / \mathrm{g}$, which may occurred due to the fact that not all activated sites were saturated. The increase of quantity of resin in contact of solution increased the quantity of metals adsorbed by the resin due to the activated sites available, which did not saturated the resin. By the reason of copper adsorption increased from $50 \%(0.5 \mathrm{~g})$ to $75 \%(\mathrm{lg})$ and iron and nickel adsorption increased from $3 \%$ and $8 \%(\mathrm{lg})$ to $10.1 \%$ and $21.5 \%(2.5 \mathrm{~g})$, respectively, the use of Ig of resin had better results.

\subsubsection{The temperature on metals adsorption}

The thermodynamics of copper adsorption by Dowex XUS 43605 were studied at $25-60^{\circ} \mathrm{C}$. Chelating resins can be endothermic (metal adsorption increases when temperature increase) or exothermic (metal adsorption decreases when temperature increase) [16].

Figure 7 depicts the results of nickel, copper and iron adsorption varying the temperature. Iron adsorption had no effect when temperature increased until $55^{\circ} \mathrm{C}$, but decreased at $60^{\circ} \mathrm{C}$, from $29.5 \mathrm{mg} / \mathrm{g}$ to $23.4 \mathrm{mg} / \mathrm{g}$. Copper adsorption had no effect when temperature increased. Consequently, there is no reason to increase the temperature in industrial process to recover copper using Dowex XUS 43605 from nickel laterite leach solution.

Copper adsorption slightly decreases in chelating resins with iminodiacetate functional groups when temperature increases $[8,20]$. For this reason, the effect of temperature must be studied for each chelating resin and solution.

\section{CONCLUSION}

The goal of this work was to evaluate the chelating resin Dowex XUS 43605 for copper recovery from nickel laterite leach solution. Monoelementary and multielementary experiments were performed to study the effect of other metals in solution on copper recovery efficiency. Results showed that the reaction reached the equilibrium at $120 \mathrm{~min}$. Copper adsorption was $100 \%$ using monoelementary solutions and $72 \%$ in multielementary solution at $\mathrm{pH} \mathrm{I.5.} \mathrm{The} \mathrm{pH}$ where the resin was more selectivity for copper was I.5. The increase of quantity of resin in solution decreased the adsorption capacity and the better result was using I $g$ of resin. Temperature has slightly effect on metals adsorption. Future studies must be focus on continuous experiments to simulate an industrial process.

\section{Acknowledgements}

The authors received financial support from the University of Sao Paulo, CNPq and the FAPESP/Capes grants 2012/5 I87I-9 and 20 16/05527-5, São Paulo Research Foundation (FAPESP). To ITV (Instituto Tecnológico da VALE).

\section{REFERENCES}

I Mudd GM. Global trends and environmental issues in nickel mining: sulfides versus laterites. Ore Geology Reviews. 20I0;38(I-2):9-26. http://dx.doi.org/I0.1016/j.oregeorev.2010.05.003.

2 Norgate T, Jahanshahi S. Assessing the energy and greenhouse gas footprints of nickel laterite processing. Minerals Engineering. 201 I;24(7):698-707. http://dx.doi.org/10.1016/j.mineng.2010.10.002. 
3 Botelho Junior AB, Dreisinger DB, Espinosa DCR. A review of nickel, copper, and cobalt recovery by chelating ion exchange resins from mining processes and mining tailings. Mining, Metallurgy \& Exploration. 2019;36(I):199-2I3.

4 Crundwell FK, Moats MS, Ramachandran V, Robinson TG, Davenport WG. Extractive metallurgy of nickel, cobalt and platinum-group metals. Oxford: Elsevier; 201 I. 583 p. [cited 2018 Jan 3]. Available at: http://linkinghub.elsevier.com/ retrieve/pii/B9780080968094I000I2.

5 Aliprandini P. O uso da extração por solventes para tratamento de licor de lixiviação de minério limonítico de níquel. São Paulo: Universidade de São Paulo; 2017.

6 Sole KC, Mooiman MB, Hardwick E. lon exchange in hydrometallurgical processing: an overview and selected applications. Journal Separation \& Purification Reviews. 2018;47(2): I59- I78. http://dx.doi.org/I0.1080/I5422II9.20I7. 1354304.

7 Inamuddin ML. lon exchange technology I. Vol. 10. New York: Springer; 2012.350 p. [cited 2018 Jan 3]. Available at: http://www.degruyter.com/doi/I0.1524/zpch.1957.10.5_6.350

8 Botelho Junior AB, Espinosa DCR, Dreisinger D, Tenório JAS. Recovery of nickel and cobalt from nickel laterite leach solution using chelating resins and pre-reducing process. Canadian Journal of Chemical Engineering. 2019;97(5): I I8I1190.

9 Perez ID, Espinosa DCR. Efeito do $\mathrm{pH}$ na adsorção de metais de uma solução sintética utilizando resina quelante Dowex XUS43605. In: Associação Brasileira de Metalurgia, Materiais e Mineração. Anais do ABM Week 2016; 2016; Rio de Janeiro, Brazil. São Paulo: ABM; 2016. p. I-9.

10 Dow Chemical Company. Ion exchange resins for chemical processing [cited 2018 Jan 3]. Available at: http:// msdssearch.dow.com/PublishedLiteratureDOWCOM/dh_07c8/090 I b803807c8488.pdfffilepath=liquidseps/pdfs/ noreg/177-02437.pdf\&fromPage= GetDoc.

II Perez ID. Recuperação de cobre de uma solução sintética baseada no licor de lixiviação atmosférica de minério limonítico de níquel por troca iônica utilizando a resina quelante Dowex XUS43605 [dissertação]. São Paulo: Universidade de São Paulo; 2018.

12 Squadrone S, Burioli E, Monaco G, Koya MK, Prearo M, Gennero S, et al. Human exposure to metals due to consumption of fish from an artificial lake basin close to an active mining area in Katanga (D.R. Congo). The Science of the Total Environment. 2016;568:679-684. http://dx.doi.org/10.10I6/j.scitotenv.2016.02.167.

13 Rudnicki P, Hubicki Z, Kołodyńska D. Evaluation of heavy metal ions removal from acidic waste water streams. Chemical Engineering Journal. 20 I4;252:362-373.

I 4 Yu Z, Qi T, Qu J, Wang L, Chu J. Removal of $\mathrm{Ca}$ (II) and Mg(II) from potassium chromate solution on Amberlite IRC 748 synthetic resin by ion exchange. Journal of Hazardous Materials. 2009;167(I-3):406-4I2.

15 Zainol Z, Nicol MJ. lon-exchange equilibria of $\mathrm{Ni2}+, \mathrm{Co} 2+, \mathrm{Mn} 2+$ and $\mathrm{Mg} 2+$ with iminodiacetic acid chelating resin Amberlite IRC 748. Hydrometallurgy. 2009;99(3-4): 175-I80. http://dx.doi.org/I0.1016/j.hydromet.2009.08.004.

16 Botelho Junior AB, Vicente ADA, Espinosa DCR, Tenório JAS. Effect of iron oxidation state for copper recovery from nickel laterite leach solution using chelating resin. Separation Science and Technology. 2019 [cited 2018 Jan 3]: I-I I. Available at: https://www.tandfonline.com/doi/full/I0.1080/01496395.2019.1574828.

17 Jiménez Correa MM, Aliprandini P, Silvas FPC, Tenório JAS, Dreisinger D, Espinosa DCR. Nickel and copper adsorption from acidic sulfate medium by ion exchange. In: Proceedings of the Conference of Metallurgists Hosting World Gold \& Nickel Cobalt; 2017; Vancouver, BC, Canada. Vancouver: Canadian Institute of Mining, Metallurgy and Petroleum; 2017.

18. Abbasi P, McKevitt B, Dreisinger DB. The kinetics of nickel recovery from ferrous containing solutions using an Iminodiacetic acid ion exchange resin. Hydrometallurgy. 2018:333-339. https://doi.org/10.1016/j. hydromet.2017.11.002.

19 Alexandratos SD. Ion-exchange resins: a retrospective from industrial and engineering chemistry research. Industrial \& Engineering Chemistry Research. 2009;48:388-398. http://dx.doi.org/10.1021/ie80 I242v.

20 Kuz'Min VI, Kuz'Min DV. Sorption of nickel and copper from leach pulps of low-grade sulfide ores using Purolite S930 chelating resin. Hydrometallurgy. 2014;141:76-8I. http://dx.doi.org/I0.1016/j.hydromet.2013.10.007.

Received: 20 Jan. 2019

Accepted: 28 Apr. 2019 